\title{
Simple and Rapid Synthesis of Calcium Acetate from Scallop Shells to Reduce Environmental Issues
}

\author{
Montree Thongkam, ${ }^{1}$ Jinnaput Saelim, ${ }^{1,2}$ Banjong Boonchom ${ }^{1},{ }^{1,2}$ Somkiat Seesanong, ${ }^{3}$ \\ Kittichai Chaiseeda $\mathbb{D}^{4}{ }^{4}$ Nongnuch Laohavisuti, ${ }^{5}$ Kanokpon Bunya-atichart, ${ }^{6}$ \\ Wimonmat Boonmee, ${ }^{7}$ and Duangkamol Taemchuay ${ }^{5}$ \\ ${ }^{1}$ Advanced Functional Phosphate Material Research Unit, Department of Chemistry, School of Science, King Mongkut's Institute of \\ Technology Ladkrabang, Bangkok 10520, Thailand \\ ${ }^{2}$ Municipal Waste and Wastewater Management Learning Center, School of Science, King Mongkut's Institute of \\ Technology Ladkrabang, Bangkok 10520, Thailand \\ ${ }^{3}$ Department of Plant Production Technology, School of Agricultural Technology, King Mongkut's Institute of \\ Technology Ladkrabang, Bangkok 10520, Thailand \\ ${ }^{4}$ Organic Synthesis, Electrochemistry and Natural Product Research Unit (OSEN), Department of Chemistry, Faculty of Science, \\ King Mongkut's University of Technology Thonburi, Bangkok 10140, Thailand \\ ${ }^{5}$ Department of Animal Production Technology and Fishery, School of Agricultural Technology, King Mongkut's Institute of \\ Technology Ladkrabang, Bangkok 10520, Thailand \\ ${ }^{6}$ Department of Agriculture, Prince of Chumphon Campus, Chumphon, King Mongkut's Institute of Technology Ladkrabang, \\ 86160, Thailand \\ ${ }^{7}$ Department of Biology, School of Science, King Mongkut's Institute of Technology Ladkrabang, Bangkok 10520, Thailand
}

Correspondence should be addressed to Banjong Boonchom; banjong.bo@kmitl.ac.th and Kittichai Chaiseeda; kittichai@gmail.com

Received 9 July 2021; Revised 28 August 2021; Accepted 31 August 2021; Published 6 October 2021

Academic Editor: Amr Nassar

Copyright (c) 2021 Montree Thongkam et al. This is an open access article distributed under the Creative Commons Attribution License, which permits unrestricted use, distribution, and reproduction in any medium, provided the original work is properly cited.

\begin{abstract}
The search for sustainable resources remains a subject of global interest. Calcium acetate used in many fields was prepared using waste scallop shell as a raw material, and its physicochemical properties were investigated. The waste scallop shells were transformed to calcium acetate compounds by reactions with four acetic acid concentrations at ambient temperature until the completely dried powder is obtained. The maximum yield of $87 \%$ with short reaction time at a low temperature was observed in the reaction of $60 \% \mathrm{w} / \mathrm{w}$ acetic acid with scallop shells. Thermal transformation reactions of all prepared calcium acetate samples revealed temperature conditions for heating to produce other advanced materials. FTIR and XRD results confirmed the purity and solid phase of all prepared calcium acetate samples, and they were compared with those of literatures and found to be well consistent. The obtained timber-like particles have different sizes depending on the acetic acid concentration. This work reports an easy and low-cost method with no environmental effect to produce cheap calcium products to be used in the industry.
\end{abstract}

\section{Introduction}

In Thailand, scallops are consumed about over 30,000 tons per year according to statistics from the Department of Agriculture and Water Resources of Thailand [1]. The edible part of the scallop composes only $20 \%$ of the total weight, leaving over 24,000 tons of shell wastes [2]. On the coast of Thailand, waste scallop shells are from byproducts of the shellfish aquaculture, processing industries, and seafood restaurants, and they are dumped into coastal areas $[1,2]$. Large 
numbers of waste scallop shells were unduly discarded, causing serious environmental problems such as soil, water, and air pollutions as well as health and sanitation problems. The statistical data shows that many tons of scallop shells were annually disposed of. Over time, microbial decomposition appeared and progressively created very toxic gases such as $\mathrm{NH}_{3}$ and $\mathrm{H}_{2} \mathrm{~S}[3,4]$. Alarmed with these problems, the Ministry of Higher Education, Science, Research, and Innovation of Thailand has introduced the Bio-Circular-Green Economic Model or BCG to resolve these problems and financed projects for recycling these wastes, including establishing factories for calcium and fertilizers production to increase the recycling quantity of waste scallop shells (WSS) [5, 6]. However, only $20 \%$ of WSS were reused [7].

Scallop shells consist of $98-99 \%$ calcium carbonate $\left(\mathrm{CaCO}_{3}\right)$ as the main chemical component and 1-2\% minor metal oxide contaminants $\left(\mathrm{Na}_{2} \mathrm{O}, \mathrm{K}_{2} \mathrm{O}, \mathrm{SO}_{3}\right.$, etc. $)$ [2, 4]. In general, $\mathrm{CaCO}_{3}$ is very cheap, abundantly available in nature (like limestone), and the sources of this compound are renewable daily [8]. Scallop shell powder can be used in various industries, for example, in the construction industry as limestone substitutes for concrete aggregates and backfills [9]. It can also be used as sand mixtures, cement mortars, clinkers [10], filter beds, and heat retardant coating plastering and paving materials [11]. In the medical and pharmaceutical industry, it is used as a calcium-enriched supplement and antimicrobial substance [2, 4, 12], while in agricultural industry, it is used as soil conditioners (soil regeneration and soil quality improvement), fertilizers [13], water treatment compounds (eutrophication control and phosphorus removal) $[8,14]$, and mineral calcium animal feed [15]. It has also been used as food additives, filler in plastics, and ceramic mixtures [2, 4, 16, 17]. Additionally, scallop shells can be utilized as starting material for preparing advanced function compounds. By heat treatment at above $700^{\circ} \mathrm{C}, \mathrm{CaCO}_{3}$ obtained from scallop shells is transformed to $\mathrm{CaO}$ which has been used in many applications [18-20]. Some researchers have synthesized hydroxyapatite (HAp) from scallop shell with different preparation methods $[21,22]$. However, using scallop shells as starting material to prepare other advanced compounds (organic calcium; acetate, lactate, citrate, etc.) still lacks information.

Calcium acetate $\left(\mathrm{Ca}\left(\mathrm{CH}_{3} \mathrm{OO}\right)_{2} \cdot 2 \mathrm{H}_{2} \mathrm{O}, \mathrm{CA}\right)$, also known as lime acetate and vinegar salts, is a calcium salt of acetic acid, which does occur naturally but is more often manufactured $[23,24]$. The anhydrous form of CA is extremely hygroscopic; therefore, the dihydrate or monohydrate forms are more common. Its hemihydrate has also been found, and the crystal structure has been studied $[25,26]$. CA can be prepared by soaking calcium carbonate (found in eggshells or in common carbonate rocks, such as limestone or marble or hydrated lime) in vinegar [27]:

$\mathrm{CaCO}_{3}(\mathrm{~s})+2 \mathrm{CH}_{3} \mathrm{COOH}(\mathrm{aq}) \longrightarrow \mathrm{Ca}\left(\mathrm{CH}_{3} \mathrm{COO}\right)_{2} \cdot \mathrm{nH}_{2} \mathrm{O}(\mathrm{s})+\mathrm{CO}_{2}(\mathrm{~g})$

$$
\mathrm{Ca}(\mathrm{OH})_{2}(\mathrm{~s})+2 \mathrm{CH}_{3} \mathrm{COOH}(\mathrm{aq}) \longrightarrow \mathrm{Ca}\left(\mathrm{CH}_{3} \mathrm{OO}\right)_{2} \cdot 2 \mathrm{H}_{2} \mathrm{O}(\mathrm{s}) .
$$

CA has been extensively reported as a promising chemical for environmental and industrial applications [28]. CA can be used in the environmental field, as the best alternative material for replacing the corrosive and environmentally unacceptable deicers (sodium chloride and calcium chloride) [23], as a powerful $\mathrm{SO}_{2}, \mathrm{NO}_{\mathrm{X}}$, and toxic particulate emission control agent in coal combustion processes to reduce acid rain [29], as an effective catalyst for the facilitation of coal combustion [30], and as an adsorbent of carbon dioxide [31]. In the food industries, it has been used as a stabilizer and preservative in many food substances under the number E263, as a stabilizer in most hard candies, as an antiroping agent in most commercially sold breads, as a stabilizer in baby food and syrups, and as coagulate soy milk in the commercial manufacture of tofu [32]. Recently, it has been used to precipitate milk fat globule membrane components from a dairy byproduct [33]. In the medical field, it has been used for treating or preventing calcium deficiency and hyperphosphatemia in patients with end-stage renal disease [34]. In the agricultural field, it has been used as a soil amendment, a plant micronutrient, foliar fertilizer, and a soil $\mathrm{pH}$ adjuster [35]. More recently, CA has been used to alleviate yield loss in rice [36] and determine the potential acidity of tropical soils [37]. For other applications, CA has been used as starting reagent to return to common compounds such as nano $\mathrm{CaO}$ [38] and $\mathrm{CaCO}_{3}$ [39] and prepare other compounds such as calcium phosphates [40], acetone [41], composite ceramic compounds [42], anhydrite calcium sulfate nanowhiskers [43], and cement mortar [44].

This report focuses on using scallop shells to synthesize CA according to the BCG model in Thailand. This work presents an alternative way to produce CA instead of using nonrenewable resources and also helps to avoid various significant adverse environmental effects. CA has been produced from eggshells $[45,46]$, but only shells of black snail [47], littleneck clam [48], and oyster [3] have been used for synthesizing CA compound. The different physicochemical properties of the CA compounds depend on the preparation method including various preparation conditions such as acetic acid concentration and reaction time. The aim of this work was to study the effect of the preparation parameters in the process such as acetic acid concentration and reaction time and the properties of the resulting CA products obtained including percentage yield, particle size, and physicochemical properties as well as the production cost. All parameters were carried out in order to find the best condition.

\section{Materials and Methods}

2.1. Materials. Specimens of the scallop shells were collected at Chonburi beach, Thailand. The scallop shells were rinsed with water to remove dust and impurities and then were dried in an oven at $110^{\circ} \mathrm{C}$ for $1 \mathrm{~h}$. Finally, they were pulverized and sieved to obtain scallop shells powder (SSP) which was smaller than 50 meshes.

Industrial-grade concentrated acetic acid (99\%w/w $\mathrm{CH}_{3} \mathrm{COOH}$, Merck) was used without further purification. This concentrated acid was diluted by deionized water to 
prepare four concentrations of acetic acid $(40,50,60$, and $70 \% \mathrm{w} / \mathrm{w})$. The dilutions were strong exothermic process; so, the solutions were left to cool before further use.

2.2. Preparation of Calcium Acetate $\left[\mathrm{Ca}\left(\mathrm{CH}_{3} \mathrm{COO}\right)_{2} \cdot 2 \mathrm{H}_{2} \mathrm{O}\right]$. In an example preparation, $40 \% \mathrm{w} / \mathrm{w}$ acetic acid (AA) was added into a beaker containing $10 \mathrm{~g}$ of SSP $\left(\mathrm{CaCO}_{3}\right)$ in the mole ratio of $\mathrm{AA}: \mathrm{SSP}=1: 2$. The mixed suspension reaction was an exothermic process and was stirred at $400 \mathrm{rpm}$ until carbon dioxide completely evolved (no more than $60 \mathrm{~min}$ ) according to Equation (1), and then it was left at room temperature until completely dry. The pale creamwhite powder was obtained and designated as CA40. For other products, the processes were repeated for different concentration of acetic acid $(50,60$, and $70 \% \mathrm{w} / \mathrm{w})$, and the products were labeled as CA50, CA60, and CA70, respectively.

2.3. Characterization of Calcium Acetate $\left[\mathrm{Ca}\left(\mathrm{CH}_{3} \mathrm{COO}\right)_{2} \cdot 2 \mathrm{H}_{2} \mathrm{O}\right]$. X-ray fluorescence (XRF) was used for analyzing the element types and amount of trace element in samples. The structure and crystallinity of samples were recorded by powder X-ray diffraction patterns (XRD; Bruker AXS, Karlsruhe, Germany), and the crystal size was calculated using Scherrer equation based on comparison of the XRD model of samples with the standard substance. The chemical molecular structures were measured by a Fourier transform infrared spectrophotometer (FTIR, Spectrum GX, Perkin Elmer, UK) from 4000 to $400 \mathrm{~cm}^{-1}$ with THE $\mathrm{KBr}$ disk method. Thermogravimetric/differential thermal analyzer (TG-DTA, Pyris Diamond, Perkin Elmer Apparatus) was implemented to calculate the TGA curve of the sample in nitrogen gas from 30 to $900^{\circ} \mathrm{C}$ at a heating rate of $5^{\circ} \mathrm{C} / \mathrm{min}$. Finally, surface morphologies of samples were inspected by a scanning electron microscope (SEM, LEO SEM VPI450) by making a gold-plated sample before analysis.

\section{Results and Discussion}

3.1. Preparation of CA. CA compounds were successfully synthesized by the reaction of SSP with four different concentrations of acetic acid $(40,50,60$, and $70 \% \mathrm{w} / \mathrm{w})$. Important parameters to evaluate for the synthesis of CA from SSP with different acetic concentrations were the yield, reaction time, and reaction temperature of the process. The production of CA from waste material is only advantageous if a high yield is attained with short reaction time and at low reaction temperature. If these parameters indicate low production cost, they will affect an economic decision of scientists and industrialists. From Table 1, the maximum yield of $87.05 \%$ was obtained from the reaction of SSP with $60 \% \mathrm{w} / \mathrm{w}$ acetic acid. However, yields of CA from each acetic acid concentration were found to be over $83 \%$ and showed no significant difference. The purity of the obtained CA products based on XRF analysis was also not significantly different, ranging from $95.34 \%$ to $98.00 \%$. It shall be noted that the yield and purity of CA products could vary depending on the species of scallops used and also where they are obtained from. The reaction temperature of the processes increased as the acetic concentration increased and was observed in the range of $35-70^{\circ} \mathrm{C}$. For the reaction time of the preparation process, it was recorded at the beginning of the reaction until the powder was completely dry by itself in the open air. The reaction time decreased as the concentration of acetic acid increased and was found to be in the range of $10-24 \mathrm{hrs}$. From the above results, the optimal condition of CA production was the reaction of SSP with $60 \% \mathrm{w} / \mathrm{w}$ acetic acid. This information could help to select the best production condition at an industrial scale. Furthermore, to the best of our knowledge, there have not been a published result on this method (SSP + acetic acid) before. In terms of economic benefit, based on these results, this method is very attractive. In the preparation of calcium acetate, scallop shells were obtained almost free because they were waste. The cost of bulk industrial grade acetic acid is about 0.6 USD per kg. In this method, $1 \mathrm{~kg}$ of scallop required about $1.2 \mathrm{~kg}$ of acetic acid (approximately 0.72 USD). The yield of about $87 \%$ would be about $1.5 \mathrm{~kg}$ of calcium acetate obtained. Adding small amount of labor cost, the cost per kg of CA from scallop shells would be about 0.5 USD. The bulk price of calcium acetate in the market is about 1 USD per kg so producing CA from scallop shells would be economically feasible. Moreover, the benefits extend beyond the cost. By producing CA from shell wastes, the environmentally hazardous wastes will be reduced.

\subsection{Characteristics of SSP and CA Compounds}

3.2.1. Thermal Properties. Figure 1 shows the TG/DTG results of SSP and CA prepared from four different acetic acid concentrations, as recorded in the temperature range from room temperature to $900^{\circ} \mathrm{C}$. As shown in Figure 1(a), the TG curve of SSP exhibited thermal stability up to $600^{\circ} \mathrm{C}$ and a single step of the decarbonization process in the temperature range from $600^{\circ} \mathrm{C}$ to $800^{\circ} \mathrm{C}$ due to $\mathrm{CO}_{2}$ release, giving $\mathrm{CaO}$ as its final stable compound. The respective DTG peak was observed at $752^{\circ} \mathrm{C}$. The thermal transformation reaction of SSP with percentage mass loss in theoretical (Theo.) and experimental (Exp.) was shown in Equation (3):

$$
\begin{array}{crcl}
\mathrm{CaCO}_{3}(\mathrm{~s})(\mathrm{SSP}) \longrightarrow \mathrm{CaO}(\mathrm{s})+\mathrm{CO}_{2}(\mathrm{~g}), & \\
100 \% & 56 \% & 44 \%, & \text { (Theo.) } \\
100 \% & 56.22 \% & 43.78 \% . & \text { (Exp.) }
\end{array}
$$

The total mass loss and remained mass of SSP reported in this work were well consistent with those of the reference and theoretical data of $\mathrm{CaCO}_{3}[3,5-7]$. The thermal property obtained indicates that SSP can be transformed to $\mathrm{CaO}$ by heating at above $752^{\circ} \mathrm{C}$, which is lower temperature than other shells $\left(800^{\circ} \mathrm{C}\right.$ for oyster shell, $753^{\circ} \mathrm{C}$ for golden apple snail shells, $900^{\circ} \mathrm{C}$ for mussel shell and cockle shell) to obtain a final decomposition product $[3,5-7]$.

The TG results of CA prepared from four different acetic acid concentrations (Figures 1(b)-1(e)) were similar with 
TABLe 1: Experimental conditions and the yield.

\begin{tabular}{|c|c|c|c|c|c|}
\hline Sample code & Concentration of acetic acid/\%w/w & Reaction temperature $/{ }^{\circ} \mathrm{C}$ & Reaction time/h & Yield/\% & Purity $/ \%$ \\
\hline CA40 & 40 & 35 & 24 & 85.04 & 95.46 \\
\hline CA50 & 50 & 42 & 20 & 83.98 & 95.34 \\
\hline CA60 & 60 & 58 & 12 & 87.05 & 98.00 \\
\hline CA70 & 70 & 64 & 10 & 86.85 & 97.44 \\
\hline
\end{tabular}

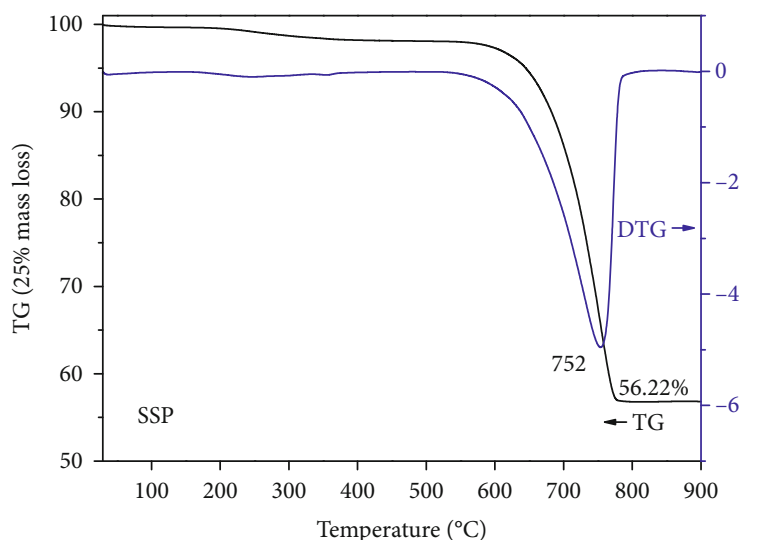

(a)

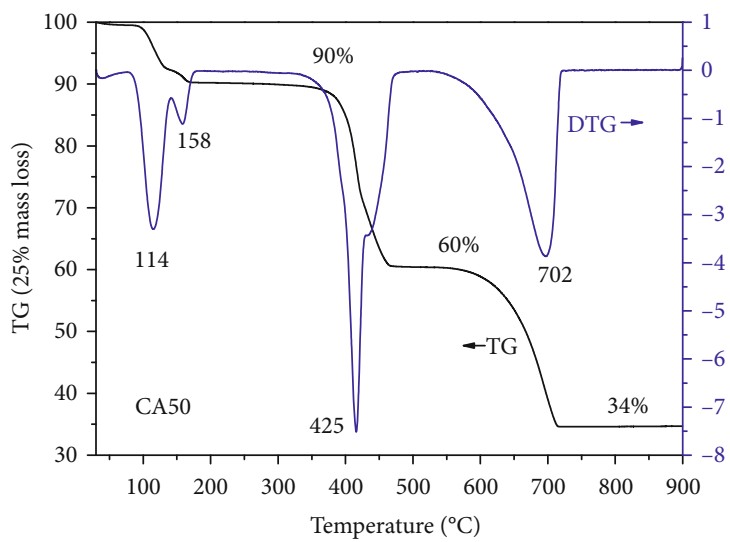

(c)

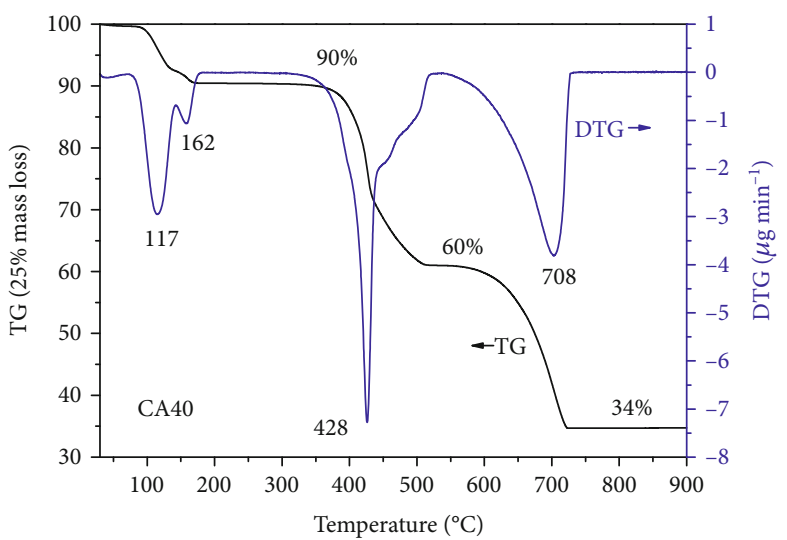

(b)

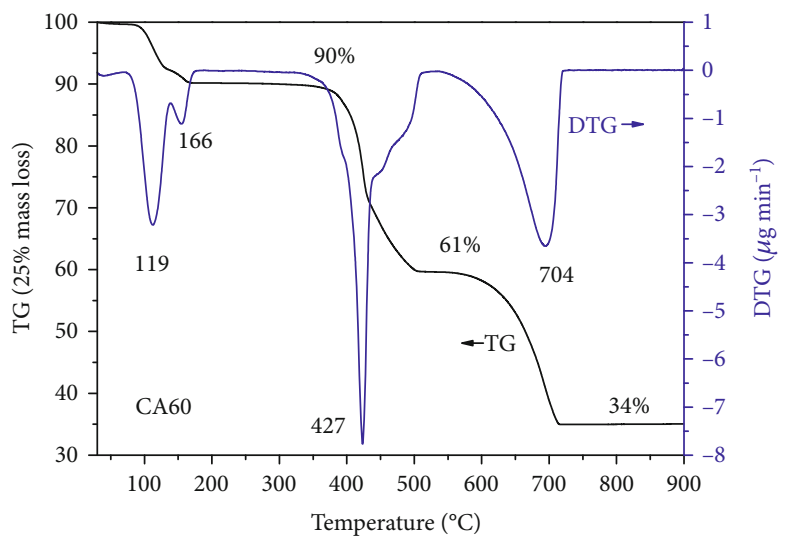

(d)

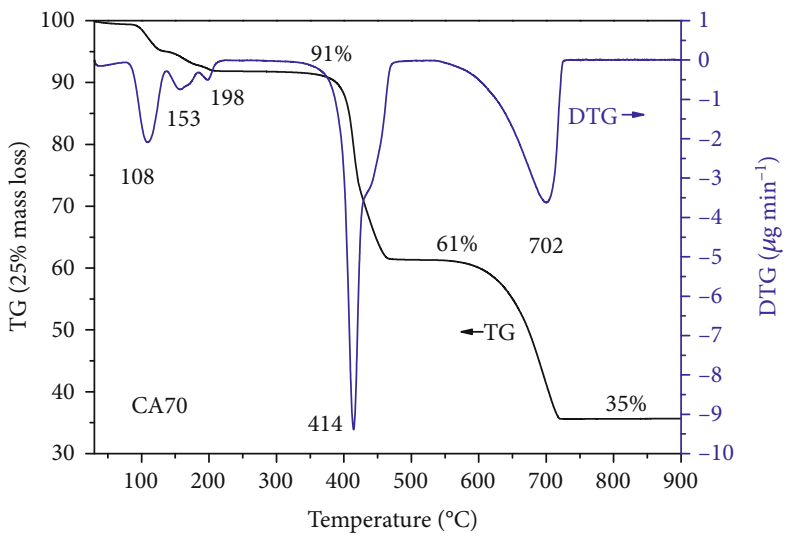

(e)

Figure 1: TG/DTG curves of SSP (a) and CA prepared from four different acetic acid concentrations: (b) 40, (c) 50, (d) 60, and (e) 70\%w/w. 
three regions of thermal transformation reaction occurred in $100-200,350-550$, and $600-750^{\circ} \mathrm{C}$. The corresponding mass losses of each CA sample were found close to 10, 30, and $25 \%$, respectively. The total mass loss was about $66 \%$, and the mass retained was about $34 \%\left(>720^{\circ} \mathrm{C}\right)$, producing $\mathrm{CaO}$ as a final stable compound. The total mass loss and the residual mass of all prepared CA products were well consistent with theoretical data. However, this result may not be in agreement with CA obtained from oyster shell [4], which reported a higher temperature $\left(>800^{\circ} \mathrm{C}\right)$ to get the $\mathrm{CaO}$. DTG curves of CA40, CA50, and CA60 were quite similar, which showed four peaks at similar temperatures at 110 , 155,420 , and $700^{\circ} \mathrm{C}$. However, only the DTG curve of the CA70 sample showed five peaks at $110,157,197,413$, and $699^{\circ} \mathrm{C}$. The first mass loss region observed in TG data corresponds to the first two peaks for CA40, CA50, and CA60 samples, and the first three peaks for the CA70 sample revealed by DTG data were assigned to the dehydration reaction of one molecule of $\mathrm{H}_{2} \mathrm{O}$. The number of two or three peaks observed in DTG curves indicated distinct water molecule in the surrounding environment within the structure, which is a characteristic from different acetic acid concentrations in the synthetic process. The second and third mass loss regions observed in TG data were related to an individual single peak that occurred in DTG curves for all prepared samples, which were assigned to the eliminations of acetate ion, forming acetone and carbon dioxide, respectively. From the TG/DTG results, the thermal transformation reactions of all prepared samples could be summarized in the following equations:

$$
\mathrm{Ca}\left(\mathrm{CH}_{3} \mathrm{COO}\right)_{2} \cdot \mathrm{H}_{2} \mathrm{O}(\mathrm{s}) \longrightarrow \mathrm{Ca}\left(\mathrm{CH}_{3} \mathrm{COO}\right)_{2} \cdot \mathrm{mH}_{2} \mathrm{O}(\mathrm{s})+\mathrm{nH}_{2} \mathrm{O}(\mathrm{g}) \text {, }
$$

$\mathrm{Ca}\left(\mathrm{CH}_{3} \mathrm{COO}\right)_{2} \cdot \mathrm{mH}_{2} \mathrm{O}(\mathrm{s}) \longrightarrow \mathrm{Ca}\left(\mathrm{CH}_{3} \mathrm{COO}\right)_{2} \cdot \mathrm{pH}_{2} \mathrm{O}(\mathrm{s})+\mathrm{kH}_{2} \mathrm{O}(\mathrm{g})$,

$$
\mathrm{Ca}\left(\mathrm{CH}_{3} \mathrm{COO}\right)_{2} \cdot \mathrm{pH}_{2} \mathrm{O}(\mathrm{s}) \longrightarrow \mathrm{Ca}\left(\mathrm{CH}_{3} \mathrm{COO}\right)_{2}(\mathrm{~s})+\mathrm{pH}_{2} \mathrm{O}(\mathrm{g}),
$$

$$
\begin{gathered}
\mathrm{Ca}\left(\mathrm{CH}_{3} \mathrm{COO}\right)_{2}(\mathrm{~s}) \longrightarrow \mathrm{CaCO}_{3}(\mathrm{~s})+\mathrm{CH}_{3} \mathrm{COCH}_{3}(\mathrm{~g}) \\
\mathrm{CaCO}_{3}(\mathrm{~s}) \longrightarrow \mathrm{CaO}(\mathrm{s})+\mathrm{CO}_{2}(\mathrm{~g}) \\
(n+k+p=1.0 \text { and } 0<m<1.0)
\end{gathered}
$$

For CA40, CA50, and CA60 samples, the dehydration reactions in Equations (4)-(6) were overlapped and occurred only in two reactions. Only the CA70 sample showed the dehydration steps according to Equations (4)-(8). The numbers of thermal transformation steps of all prepared CA samples were different from CA obtained from oyster shells reported in previous work [3]. Additionally, the thermal results obtained reveal the specific calcination temperatures for the synthesis of other advanced compounds (calcium acetate anhydrous, calcium carbonate, acetone, and calcium oxide) from CA starting agent like in this work, which may be interesting for material scientists and industrialists.

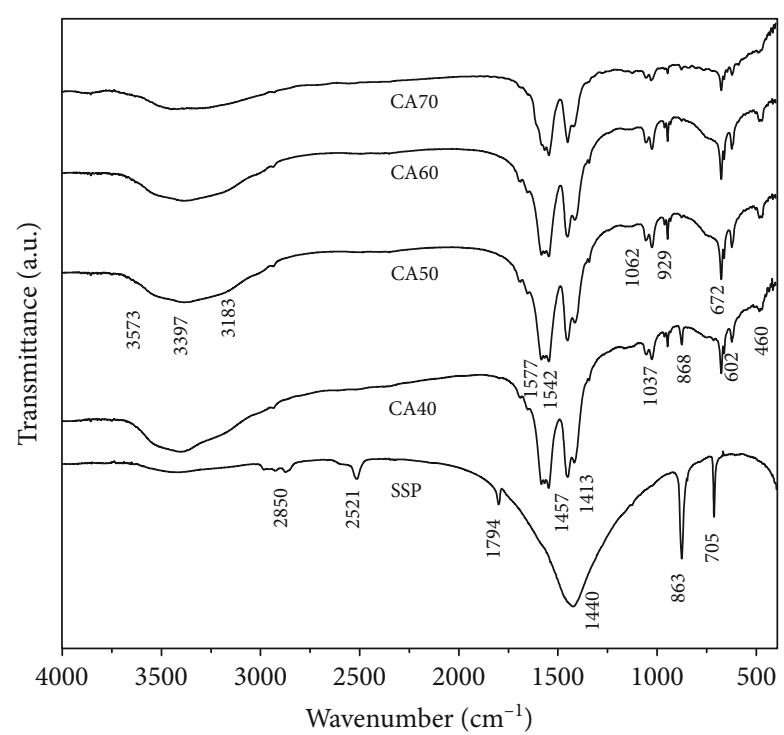

FIGURE 2: FTIR spectra of SSP and CA prepared from four different acetic acid concentrations (CA40, CA50, CA60, and CA70).

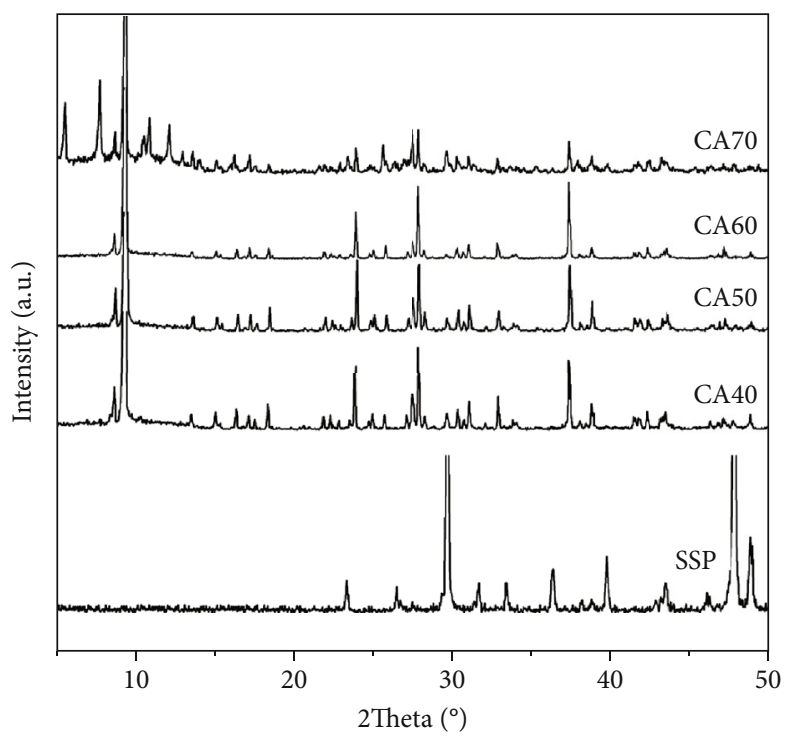

FIGURE 3: XRD patterns of SSP and CA prepared from four different acetic concentrations (CA40, CA50, CA60, and CA70).

3.2.2. Vibrational Results. FTIR spectra of SSP and CA prepared by various acetic acid concentrations are shown in Figure 2. FTIR spectrum of SSP (Figure 2(a)) exhibited fundamental vibration of $\mathrm{CO}_{3}{ }^{2-}$ anion as block unit in $\mathrm{CaCO}_{3}$ structure [3, 5-7]. The prominent absorption peak of $\mathrm{CO}_{3}{ }^{2-}$ at $1440 \mathrm{~cm}^{-1}$ was related to the asymmetric stretching mode of $\mathrm{C}-\mathrm{O}$ bond. A band at $1749 \mathrm{~cm}^{-1}$ was due to the carbonyl $v(\mathrm{C}=\mathrm{O})$ stretching vibration. The vibrational peaks at 863 and $705 \mathrm{~cm}^{-1}$ were assigned to the symmetric stretching mode of $\mathrm{C}-\mathrm{O}$ bond, out of plane and in plane bending of $\mathrm{CO}_{3}{ }^{2-}$ anion, respectively. A weak band at $2552 \mathrm{~cm}^{-1}$ and a broad band around $2850 \mathrm{~cm}^{-1}$ could be assigned to combination and overtone of the asymmetric and symmetric stretching modes of $\mathrm{C}-\mathrm{O}$ bond. These vibrational modes are 


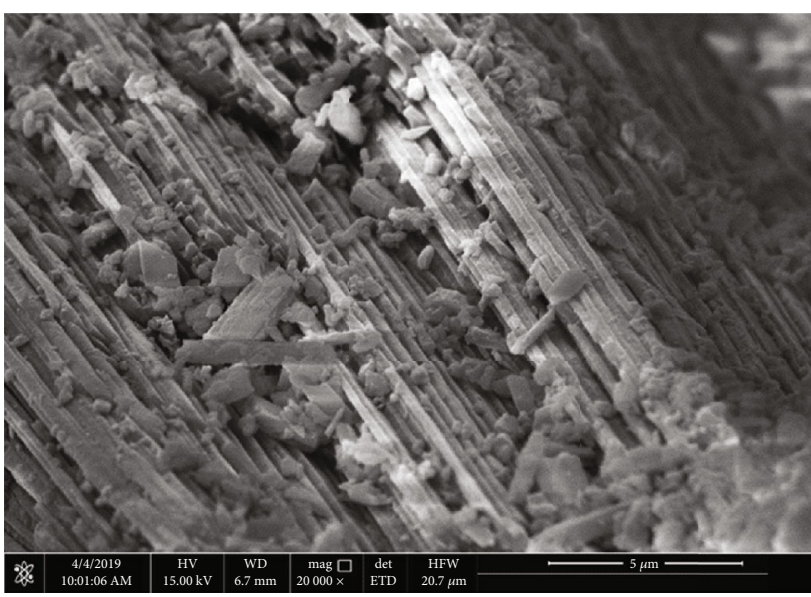

(a)

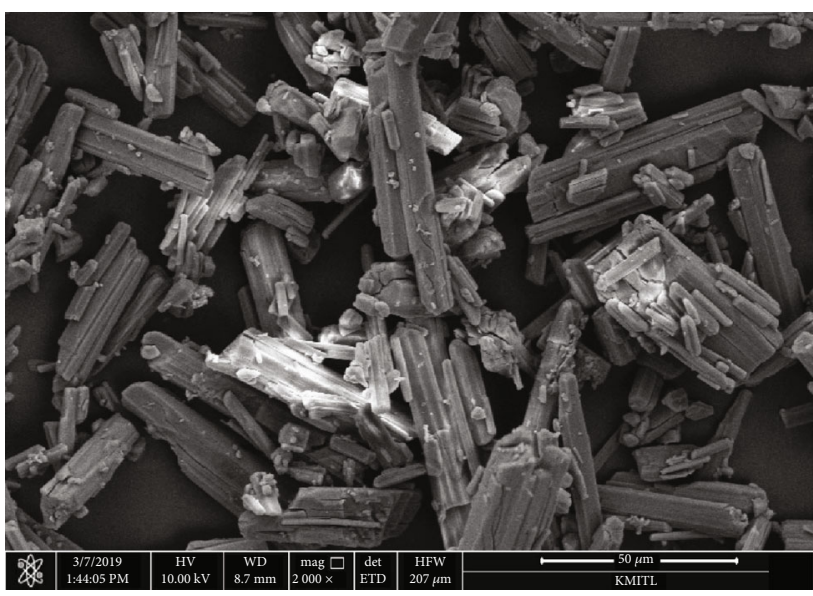

(c)

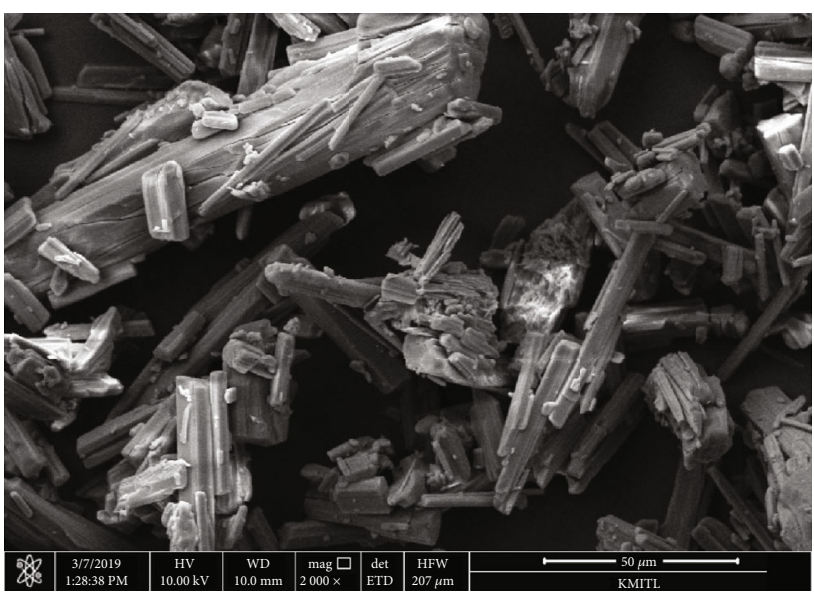

(b)

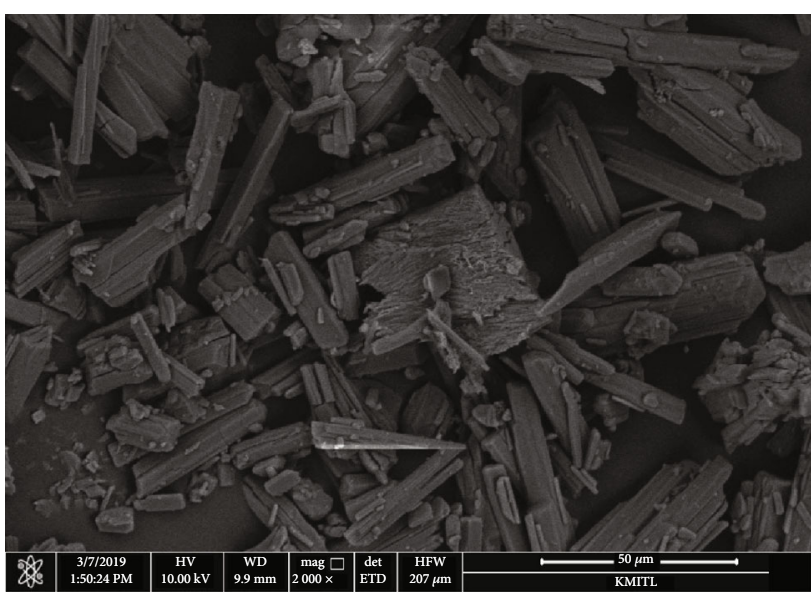

(d)

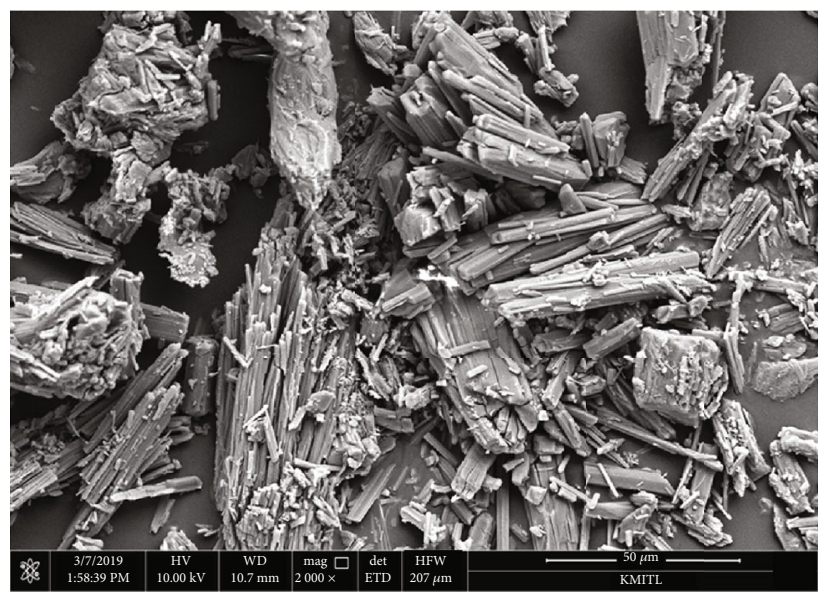

(e)

FIGURE 4: SEM micrographs of SSP (a) and CA prepared from four different acetic acid concentrations: (b) 40, (c) 50, (d) 60, and (e) $70 \% \mathrm{w} / \mathrm{w}$.

confirmed as the $\mathrm{CO}_{3}{ }^{2-}$ of aragonite phase of calcium carbonate [5-7]. The broad bands in the region from 2700 $3600 \mathrm{~cm}^{-1}$ were due to vibrational bands of methyl stretching (the antisymmetric $v_{\text {as }}\left(\mathrm{CH}_{3}\right)$ and symmetric $v_{\mathrm{s}}\left(\mathrm{CH}_{3}\right)$ ) and water molecule (the antisymmetric $v_{\text {as }}(\mathrm{OH})$ and symmetric $\left.v_{\mathrm{s}}(\mathrm{OH})\right)$. Two strong bands observed at 1577 and $1542 \mathrm{~cm}^{-}$
${ }^{1}$ were due to antisymmetric $\mathrm{C}-\mathrm{O}\left(v_{\text {as }}(\mathrm{C}-\mathrm{O})\right)$ stretching vibrations, while two intense bands at 1457 and $1413 \mathrm{~cm}^{-1}$ may be attributed to the symmetric stretching vibration of the $\mathrm{C}-\mathrm{O}$ bond $\left(v_{\mathrm{s}}(\mathrm{C}-\mathrm{O})\right)$. The out of plane stretching vibration of the methyl group $\left(\rho_{\mathrm{op}}\left(\mathrm{CH}_{3}\right)\right)$ was split into two peaks at 1062 and $1037 \mathrm{~cm}^{-1}$. The $v(\mathrm{C}-\mathrm{C})$ stretching vibration of 
the acetate anion was split into two peaks at 929 and $868 \mathrm{~cm}^{-1}$ for CA40 sample, while CA50, CA60, and CA70 samples showed a single peak at $929 \mathrm{~cm}^{-1}$. Two poorly defined peaks at 620 and $613 \mathrm{~cm}^{-1}$ were due to out of place stretching vibration of the O-C-O fragment $\left(\rho_{\text {op }}(\mathrm{OCO})\right)$ of the acetate anion. Finally, the single weak band evident in all spectra of CA samples at around $460 \mathrm{~cm}^{-1}$ was due to the inplane bending vibration of the OCO fragment $\rho_{\text {ip }}(\mathrm{OCO})$ of the acetate anion.

3.2.3. Crystallographic Results. Figure 3 shows X-ray diffraction patterns of SSP and CA samples prepared from four different acetic acid concentrations. The XRD results were compared with those of calcium carbonate and calcium acetate reported in other literatures [3, 21, 23, 27, 47, 48]. The XRD pattern of SSP clearly showed that the phase present was calcite, which was found to match with the JCPDS data file of $\mathrm{CaCO}_{3}$ (File no. 01-085-1108) [3, 21]. The XRD patterns of CA40, CA50, and CA60 samples were quite similar and were slightly different from that of CA70 especially at below $7^{\circ}$. This indicates that phase of calcium acetate monohydrate of CA70 was different from other three samples. All patterns of CA samples were in good agreement with the reference data given by Sebastian et al. [27, 49, 50] and agreed with observations from IR and TGA. Some peak intensities differ, which is ascribed to the fact that the reference data relating to flat plate (Bragg-Brentano Geometry) measurements and therefore, this may be affected by preferred orientation effects. There is no doubt that these products are calcium acetate monohydrate. This could have been corrected (i.e., indexed or fitted); however, it was not deemed necessary based on the supporting chemical characterization.

3.2.4. Morphology Results. Scanning electron microscopy (SEM) images of the SSP and CA samples prepared from four different acetic acid concentrations are illustrated in Figure 4 and were significantly different. The morphology of the SSP sample exhibited a pronounced wood-like pattern with lengths up to $100 \mu \mathrm{m}$ and agglomeration (Figure 4(a)). The crystallites of four CA samples shown in Figures 4(b)4(e) exhibited similar morphologies, which showed agglomeration like small and large timbers with dimensions in the range of $2-60 \mu \mathrm{m}$. The particle size distributions increased as the acetic acid concentration increased. The timber-like morphology for CA70 sample occurred more than those of other samples. The morphologies of all prepared CA particles obtained from this work were different in sizes and shapes from CA obtained from oyster shell, ash of black snail, and littleneck clam shell powder in previous reports $[3,47,48]$. These results indicate that the starting reagents for preparation have the strong effect on the morphology of CA, which is well consistent with what stated in the literature [27].

\section{Conclusions}

Calcium acetate (CA) was prepared successfully from the calcite phase of calcium carbonate obtained from waste scallop shells with various acetic acid concentrations $(40,50,60$, and $70 \% \mathrm{w} / \mathrm{w})$. Through an experimental design, the efficiency of the preparation of CA was studied, considering the effect of four experimental conditions (acetic acid concentration, ambient temperature, time consumption, and yield of the process). It was found that the maximum yield of CA obtained was prepared from $60 \%$ w/w acetic acid with short reaction time and low reaction temperature. The thermal properties of CA samples prepared from four different acetic acid concentrations revealed temperature conditions for the synthesis of other advanced compounds. FTIR and $\mathrm{XRD}$ results of all prepared CA samples were compared with those of previous reports, which were well consistent. The thermal analysis, FTIR, and XRD confirmed the purity and solid phase of all prepared CA as calcium acetate monohydrate. The obtained particles had timber-like appearance having different sizes depending on the acetic acid concentrations. This work adds valuable information for the alternative CA production for many applications based on starting waste materials (scallop shells) with the potential to replace lime or dolomite ores obtained from non-living things with limited resources.

\section{Data Availability}

The data used to support the findings of this study are included within the article.

\section{Conflicts of Interest}

The authors declared no potential conflicts of interest with respect to the research, authorship, and/or publication of this article.

\section{Acknowledgments}

The authors would like to thank the Scientific Instruments Center KMITL for supporting TGA, FTIR, XRD, and SEM techniques. This work was supported by the Thailand Science Research and Innovation (TSRI) (RE-KRIS/008/64).

\section{References}

[1] FAO yearbook, Fishery and Aquaculture Statistics 2016, FAO, Rome, 2018.

[2] J. Sawai, "Antimicrobial characteristics of heated scallop shell powder and its application," Biocontrol Science, vol. 16, no. 3, pp. 95-102, 2011.

[3] K.-H. Chung, S.-C. Jung, and B.-G. Park, "Eco-friendly deicer prepared from waste oyster shells and its deicing properties with metal corrosion," Environmental Technology, vol. 42, no. 21, pp. 3360-3368, 2021.

[4] N. Gultekin and E. Kucukates, "Evaluation of antimicrobial activity of scallop shell powder against Staphylococci species and gram negative bacteria isolated from patients intensive care units," Biomedical Journal of Scientific \& Technical Research, vol. 13, no. 4, pp. 10176-10180, 2019.

[5] S. Seesanong, C. Laosinwattana, and B. Boonchom, "Microparticles of calcium carbonate $\mathrm{CaCO}_{3}$, calcium hydrogen phosphate hydrate $\mathrm{CaHPO}_{4} \cdot 1.9 \mathrm{H}_{2} \mathrm{O}$ and tricalcium phosphate $\mathrm{Ca}_{3}\left(\mathrm{PO}_{4}\right)_{2}$ prepared from golden apple snail shells (Pomacea 
canaliculata)," Research Journal of Chemistry and Environment, vol. 24, no. 3, pp. 1-6, 2020.

[6] S. Seesanong, C. Laosinwattana, K. Chaiseeda, and B. Boonchom, "A simple and rapid transformation of golden apple snail (Pomacea canaliculata) shells to calcium carbonate, monocalcium and tricalcium phosphates," Asian Journal of Chemistry, vol. 31, no. 11, pp. 2522-2526, 2019.

[7] A. Buasri, N. Chaiyut, V. Loryuenyong, P. Worawanitchaphong, and S. Trongyong, "Calcium oxide derived from waste shells of mussel, cockle, and scallop as the heterogeneous catalyst for biodiesel production," Scientific World Journal, vol. 2013, pp. 1-7, 2013.

[8] S. H. Yeom and K.-Y. Jung, "Recycling wasted scallop shell as an adsorbent for the removal of phosphate," Journal of Industrial and Engineering Chemistry, vol. 15, no. 1, pp. 40-44, 2009.

[9] U. G. Eziefula, J. C. Ezeh, and B. I. Eziefula, "Properties of seashell aggregate concrete: a review," Construction and Building Materials, vol. 192, pp. 287-300, 2018.

[10] S. Her, T. Park, E. Zalnezhad, and S. Bae, "Synthesis and characterization of cement clinker using recycled pulverized oyster and scallop shell as limestone substitutes," Journal of Cleaner Production, vol. 278, article 123987, 2021.

[11] D. H. Nguyen, M. Boutouil, N. Sebaibi, L. Leleyter, and F. Baraud, "Valorization of seashell by-products in pervious concrete pavers," Construction and Building Materials, vol. 49, pp. 151-160, 2013.

[12] Y. Xu, J. Ye, D. Zhou, and L. Su, "Research progress on applications of calcium derived from marine organisms," Scientific Reports, vol. 10, no. 1, article 18425, 2020.

[13] K. N. Ghimire, H. Kai, K. Inoue et al., "Heavy metal removal from contaminated scallop waste for feed and fertilizer application," Bioresource Technology, vol. 99, no. 7, pp. 24362441, 2008.

[14] N. Chen, W. Hu, C. Feng, and Z. Zhang, "Removal of phosphorus from water using scallop shell synthesized ceramic biomaterials," Environmental Earth Sciences, vol. 71, no. 5, pp. 2133-2142, 2014.

[15] Y. C. Liu and Y. Hasegawa, "Reducing effect of feeding powdered scallop shell on the body fat mass of rats," Bioscience, Biotechnology, and Biochemistry, vol. 70, no. 1, pp. 86-92, 2006.

[16] J. Sawai, K.-j. Nagasawa, and M. Kikuchi, "Ability of heated scallop-shell powder to disinfect Staphylococcus aureus biofilm," Food Science and Technology Research, vol. 19, no. 4, pp. 561-568, 2013.

[17] M. Sophia and N. Sakthieswaran, "Waste shell powders as valuable bio- filler in gypsum plaster - Efficient waste management technique by effective utilization," Journal of Cleaner Production, vol. 220, pp. 74-86, 2019.

[18] J. Sawai, H. Shiga, and H. Kojima, "Kinetic analysis of the bactericidal action of heated scallop-shell powder," International Journal of Food Microbiology, vol. 71, no. 2-3, pp. 211-218, 2001.

[19] M. Kouzu, A. Kajita, and A. Fujimori, "Catalytic activity of calcined scallop shell for rapeseed oil transesterification to produce biodiesel," Fuel, vol. 182, pp. 220-226, 2016.

[20] A. Tsuruma, Y. Nomoto, M. Nishio, M. Ishikawa, and J. Sawai, "Efficacy of sorbitol-coated heated scallop-shell powder for the antimicrobial treatment of fresh vegetables," Food Control, vol. 110, article 106972, 2020.
[21] J. Kobayashi and K. N. Wijaya, "Shape specificity of crystal of hydroxyapatite synthesized by sol-gel method from scallop shell," Resources Processing, vol. 64, no. 3, pp. 75-77, 2017.

[22] F. Y. Syafaat and Y. Yusuf, "Influence of $\mathrm{Ca} / \mathrm{P}$ concentration on hydroxyapatite (HAp) from Asian moon scallop shell (Amusium Pleuronectes)," International Journal of Nanoelectronics \& Materials, vol. 12, no. 3, pp. 357-362, 2019.

[23] D. Dionysiou, M. Tsianou, and G. Botsaris, "Extractive crystallization for the production of calcium acetate and magnesium acetate from carbonate sources," Industrial \& Engineering Chemistry Research, vol. 39, no. 11, pp. 4192-4202, 2000.

[24] X. Jiang, G. Li, and Z. Wu, "Deicing and corrosive performances of calcium acetate deicer made from bamboo-vinegar," International Journal of Chemical and Molecular Engineering, vol. 4, no. 5, pp. 303-309, 2010.

[25] B. F. Abrahams, C. J. Commons, T. A. Hudson, and R. W. Sanchez Arlt, "The elusive crystals of calcium acetate hemihydrate: chiral rods linked by parallel hydrophilic strips," CrystEngComm, vol. 23, no. 3, pp. 707-713, 2021.

[26] S. Bette, J. Stelzner, G. Eggert et al., "Corrosion of heritage objects: collagen-like triple helix found in the calcium acetate hemihydrate crystal structure," Angewandte Chemie International Edition, vol. 59, no. 24, pp. 9438-9442, 2020.

[27] S. Bette, G. Eggert, S. Emmerling, M. Etter, T. Schleid, and R. E. Dinnebier, "Crystal structure, polymorphism, and anisotropic thermal expansion of $\alpha-\mathrm{Ca}\left(\mathrm{CH}_{3} \mathrm{COO}\right)_{2}$," Crystal Growth \& Design, vol. 20, no. 8, pp. 5346-5355, 2020.

[28] D.-M. Kim, H.-S. Ryu, S.-H. Shin, and W.-J. Park, "Properties of calcium acetate manufactured with etching waste solution and limestone sludge as a cementitious high-early-strength admixture," Advances in Materials Science and Engineering, vol. 2016, Article ID 2920370, 9 pages, 2016.

[29] J. Steciak, Y. A. Levendis, and D. L. Wise, "Effectiveness of calcium magnesium acetate as dual $\mathrm{SO}_{2}-\mathrm{NO}_{\mathrm{x}}$ emission control agent," AICHE Journal, vol. 41, no. 3, pp. 712-722, 1995.

[30] J. Steciak, W. Zhu, Y. A. Levendis, and D. L. Wise, "The effectiveness of calcium (magnesium) acetate and calcium benzoate as NOxReduction agents in coal combustion," Combustion Science and Technology, vol. 102, no. 1-6, pp. 193-211, 1994.

[31] D. Uysal Ziraman, Ö. M. Doğan, and B. Z. Uysal, "Kinetics of chemical absorption of carbon dioxide into aqueous calcium acetate solution," International Journal of Chemical Kinetics, vol. 52, no. 4, pp. 251-265, 2020.

[32] J. Y. Lu, E. Carter, and R. A. Chung, "Use of calcium salts for soybean curd preparation," Journal of Food Science, vol. 45, no. 1, pp. 32-34, 1980.

[33] N. Price, T. Fei, S. Clark, and T. Wang, "Application of zinc and calcium acetate to precipitate milk fat globule membrane components from a dairy by-product," Journal of Dairy Science, vol. 103, no. 2, pp. 1303-1314, 2020.

[34] C. R. Nolan and W. Y. Qunibi, "Calcium salts in the treatment of hyperphosphatemia in hemodialysis patients," Current Opinion in Nephrology and Hypertension, vol. 12, no. 4, pp. 373-379, 2003.

[35] R. Borchert, "Calcium acetate induces calcium uptake and formation of calcium-oxalate crystals in isolated leaflets of Gleditsia triacanthos L," Planta, vol. 168, no. 4, pp. 571578, 1986.

[36] K. Lakaew, S. Akeprathumchai, and P. Thiravetyan, "Foliar spraying of calcium acetate alleviates yield loss in rice (Oryza sativaL.) by induced anti-oxidative defence system under 
ozone and heat stresses," Annals of Applied Biology, vol. 178, no. 2, pp. 414-426, 2021.

[37] M. B. Soares, M. Y. Kamogawa, and L. R. F. Alleoni, "Adaptation of calcium acetate methodology to determine the potential acidity of tropical soils," Communications in Soil Science and Plant Analysis, vol. 51, no. 21, pp. 2701-2711, 2020.

[38] X. Liu, J. Shi, L. He, X. Ma, and S. Xu, "Modification of CaObased sorbents prepared from calcium acetate for $\mathrm{CO}_{2}$ capture at high temperature," Chinese Journal of Chemical Engineering, vol. 25, no. 5, pp. 572-580, 2017.

[39] J. Prah, J. Maček, and G. Dražič, "Precipitation of calcium carbonate from a calcium acetate and ammonium carbamate batch system," Journal of Crystal Growth, vol. 324, no. 1, pp. 229-234, 2011.

[40] T. V. Safronova, E. A. Mukhin, V. I. Putlyaev et al., "Amorphous calcium phosphate powder synthesized from calcium acetate and polyphosphoric acid for bioceramics application," Ceramics International, vol. 43, no. 1, pp. 1310-1317, 2017.

[41] M. N. Abbas, S. A. Ibrahim, Z. N. Abbas, and T. A. Ibrahim, "Eggshells as a Sustainable Source for Acetone Production," Journal of King Saud University-Engineering Sciences, 2021.

[42] K. H. Omran, M. Mostafa, M. S. Abd El-sadek, O. M. Hemeda, and R. Ubic, "Effects of Ca doping on structural and optical properties of PZT nanopowders," Results in Physics, vol. 19, article 103580, 2020.

[43] S. Chen, J. Fu, X. He et al., "Microemulsion synthesis of anhydrous calcium sulfate nanowhiskers with calcium acetate solution and its surface structure stable and crystal phase evolution after modification," Journal of Nanoparticle Research, vol. 22, no. 7, p. 193, 2020.

[44] K. Cao, L. Wang, Y. Xu, W. Shen, and H. Wang, "The hydration and compressive strength of cement mortar prepared by calcium acetate solution," Advances in Civil Engineering, vol. 2021, Article ID 8817725, 9 pages, 2021.

[45] H. Zhang, Z. Zhang, Y. Zhao, and Y. Liu, "Preparation of calcium magnesium acetate snow melting agent using raw calcium acetate-rich made from eggshells," Waste and Biomass Valorization, vol. 11, no. 12, pp. 6757-6767, 2020.

[46] L. C. S. Nobre, S. Santos, A. M. F. Palavra, M. J. F. Calvete, C. A. N. de Castro, and B. P. Nobre, "Supercritical antisolvent precipitation of calcium acetate from eggshells," Journal of Supercritical Fluids, vol. 163, article 104862, 2020.

[47] M.-Y. Lee, Y.-K. Lee, and S.-D. Kim, "Quality characteristics of calcium acetate prepared with vinegars and ash of black snail," Journal of The Korean Society of Food Science and Nutrition, vol. 33, no. 3, pp. 593-597, 2004.

[48] S. H. Park, S. J. Jang, H. J. Lee et al., “Optimization of calcium acetate preparation from littleneck clam (Ruditapes philippinarum) shell powder and its properties," Korean Journal of Food Science and Technology, vol. 47, no. 3, pp. 321-327, 2015.

[49] E. A. Klop, A. Schouten, P. Van Der Sluis, and A. L. Spek, "Structure of calcium acetate monohydrate, Ca $\left(\mathrm{C}_{2} \mathrm{H}_{3} \mathrm{O}_{2}\right)_{2} \cdot \mathrm{H}_{2} \mathrm{O}$," Acta Crystallographica Section C, vol. 40, no. 1, pp. 51-53, 1984.

[50] P. Van Der Sluis, A. Schouten, and A. L. Spek, "Structure of a second polymorph of calcium acetate monohydrate," Acta Crystallographica Section C, vol. 43, no. 10, pp. 1922-1924, 1987. 